\title{
Ontogeny of Growth Factor Receptors in the Human Placenta
}

\author{
CHERI L. DEAL, HARVEY J. GUYDA, ${ }^{(65)}$ WEI H. LAI, AND BARRY I. POSNER \\ McGill University-Montreal Children's Hospital Research Institute, and Departments of Pediatrics [C.L.D., H.J.G., \\ W.H.L.] and Medicine [H.J.G., B.I.P.], McGill University, Montreal, Quebec, Canada
}

\begin{abstract}
Summary
The present study was undertaken to further elucidate the role during gestation of insulin, epidermal growth factor-urogastrone (EGF-URO), and a slightly acidic insulin-like growth factor we have referred to as insulin-like activity (ILAs). We examined the ontogeny of the placental receptors for these peptides utilizing membrane fractions $(600 \times g, 15,000 \times g, 100,000 \times g)$ and cytosol $(200,000 \times g$ supernatant $)$ prepared by differential centrifugation of early gestation (11-19 wk) and term gestation (38-42 week) human placentae. Aliquots of each membrane fraction were also assayed for $5^{\prime}$ nucleotidase activity. The ontogeny of the insulin and EGF receptors closely resembled the pattern of $5^{\prime}$ nucleotidase activity, with greater levels seen in term tissue for all membrane fractions assayed. Highest levels of specific binding per $\mathrm{mg}$ protein and enzyme specific activity were seen in the $100,000 \times g$ fraction within either gestational age group. The pattern of $\left[^{125} I\right]-I L A s$ specific binding was quite different: binding per $\mathrm{mg}$ protein was higher in membranes from early gestation placentae regardless of the fraction, with the biggest differential occurring in the $600 \times g$ pellet. As observed with [ $\left.{ }^{125} I\right]$-insulin and $\left[{ }^{125} I\right]$-EGF, the 100,000 $\times g$ pellets from either age group were also enriched in [ $\left.{ }^{125} \mathrm{I}\right]-\mathrm{ILAs}$ binding. Although neither early gestation nor term cytosol bound $\left[{ }^{125} I \mid\right.$-insulin or $\left[{ }^{125} I \mid-E G F\right.$, binding of $\left.\left.\right|^{125} I\right]$-ILAs to both gestational age groups was clearly demonstrable with significantly higher levels observed in cytosol from early gestation placentae.
\end{abstract}

\section{Speculation}

A knowledge of the mechanisms involved in placental growth may well be a prerequisite to a full understanding of fetal growth control. The demonstration of specific human placental receptors for insulin, EGF-URO, and ILAs as early as 11-19 wk of gestation suggests that these peptides should continue to receive attention as possible modulators of placental growth and function. Furthermore, the high levels of ${ }^{125}$ I]-ILAs specific binding to membrane and cytosols from early gestation placentae may indicate a more important role for the insulin-like growth factors compared to insulin or EGF-URO during early placental development.

Clinicians are becoming increasingly aware that a knowledge of the mechanisms involved in placental growth may well be a prerequisite to a full understanding of fetal growth control (5). Possible trophic influences on the placenta include the anabolic peptides insulin, epidermal growth factor-urogastrone (EGFURO), and the family of insulin-like growth factors (IGFs): somatomedins $\mathrm{A}$ and $\mathrm{C}(\mathrm{Sm} \mathrm{A}$ and $\mathrm{C})$, insulin-like growth factors I and II (IGF I and II), insulin-like activity (ILAs), and multiplication stimulating activity (MSA). Their growth-promoting effects on cellular metabolism in a variety of tissues have recently been reviewed $(8,40-42)$.

Interest in these particular hormones/factors as modulators of placental metabolism has been fuelled, in part, by the demonstra- tion of specific, membrane-associated receptors in the human placenta $(25,36,38,43,46,48,54,57)$, two of which (for insulin and EGF-URO) have been partially purified $(26,28,60)$. Placental cytosolic binding proteins for some of the IGFs have also been described $(7,22)$.

Despite the increasing wealth of information on the biochemistry of these receptors in the placenta and other tissues, surprisingly little is known about the developmental changes in the binding of insulin, EGF-URO, or IGFs to the human placenta during gestation, or the effects of these hormones/factors on human placental metabolism. Insulin has been the best characterized to date, and appears to bind in increasing amounts as gestation progresses (43). It has been shown to stimulate term placental glucose uptake $(20,33,58)$, glycogen synthesis $(15,33)$, lactic acid and $\mathrm{CO}_{2}$ production $(20,33)$, protein synthesis (34), and lipogenesis (20), although some controversy exists $(11,53)$. Insulin effects on amino acid transport are reportedly absent (34, 51). Comparative ontogeny and stimulation data for EGF-URO and the IGFs are not available, although EGF-URO has been found to promote the phosphorylation of placental membrane proteins (9), and in the case of tumor-derived placental cell cultures it has also been shown to stimulate hCG (6) and progesterone (4) production.

The present study was undertaken to further elucidate the role of insulin, EGF-URO, and ILAs during gestation. We have examined the ontogeny of the placental receptors for all of these peptides utilizing fractions prepared by differential centrifugation of early gestation and term human placentae.

\section{MATERIALS AND METHODS}

Tissue collection and fractionation. Dr. B. Murphy of the Montreal General Hospital Research Institute kindly provided 16 early gestation placentae for this study (referred to as 'midterm' tissue). They were collected over a 3-year period at the time of hysterotomy and stored frozen at $-20^{\circ} \mathrm{C}$. The following gestational ages were included: 11.5 wk (1), 13 wk (1), 13.5 wk (1), 16 wk (2), 17 wk (4), 18 wk (4), 18.5 wk (1), 19 wk (1). All were obtained from normal, nondiabetic pregnancies. A 29 -wk caesarian section placenta was also included in the study but the data are not reported in the present paper due to the unavailability of additional samples in this gestational age range.

The 16 full-term (38-40 wk) placentae collected for comparative purposes were vaginally delivered after normal, nondiabetic pregnancies. They were trimmed free of membranes, rinsed in $0.3 \mathrm{M}$ sucrose, sectioned into $50 \mathrm{~g}$ portions, and stored frozen at $-20^{\circ} \mathrm{C}$. The storage age of the term placentae extended up to 2 years.

Eight term or mid-term placentae were processed at any one time, and duplicate membrane preparations were obtained on separate occasions for each sample. This resulted in a total of 64 homogenizations ( 15 midterm, $129 \mathrm{wk}, 16$ term). Three membrane pellets $(600 \times g, 15,000 \times g, 100,000 \times g)$ were obtained by differential centrifugation of homogenates according to the methodology of Posner (43). At the time of membrane preparation, 5 
$\mathrm{g}$ of tissue was cut from the frozen placentae; care was taken to avoid the chorionic plate and associated membranes visible in some of the mid-term placentae.

The resultant pellets from the three centrifugations were suspended in $25 \mathrm{ml}$ of a mixture of $25 \mathrm{mM}$ Tris- $\mathrm{HCl}(\mathrm{pH} \mathrm{7.4)}$ and 10 $\mathrm{mM} \mathrm{MgCl} 2$ (Tris buffer), homogenized with either a Dounce $(600$ $\times g$ and $15,000 \times g$ pellets) or a hand homogenizer $(100,000 \times g$ pellet), and recentrifuged. The washed pellets were resuspended in Tris buffer and stored in aliquots $(5-15 \mathrm{mg}$ protein/ml) at $-40^{\circ} \mathrm{C}$ until all samples had been processed (total storage time before completion of study was 4 months). The cytosol for the soluble receptor studies was obtained by centrifugation of the $100,000 \times g$ sucrose supernatants at $200,000 \times g$ for $2 \mathrm{~h}$, as described by Guyda and Posner (22).

Additional midterm and term tissue was used to obtain the displacement studies of Figure 4; gestational ages are given in the figure legend. The centrifugation protocol described above was used to obtain membrane pellets and cytosol fractions, which were stored frozen (4 days) before their use in the receptor and cytosol binding assays.

Protein determination and $5^{\prime}$ nucleotidase activity. An aliquot of each membrane fraction and each cytosol was assayed in duplicate for protein on two separate occasions by the method of Lowry et al. (35), using a bovine serum albumin (BSA) standard curve. Aliquots of membrane were dissolved in $0.6 \mathrm{~N} \mathrm{NaOH}$ by boiling $20 \mathrm{~min}$ in a water bath. Sixteen placental samples (three membrane fractions for each sample) were assayed at any one time ( 8 midterm and 8 term placentae of the same duplicate).

An aliquot of each membrane fraction was also assayed in duplicate for $5^{\prime}$ nucleotidase (E.C. 3.1.3.5) activity by the method of Aronson and Touster (3). The inorganic phosphate released during the assay was quantitated by the colorimetric method described by Ames et al. (2). Parallel incubation tubes containing adenosine $5^{\prime}$ monophosphoric acid (5' AMP, Sigma) plus $10 \mathrm{mM}$ $\mathrm{NaK}$ tartrate were included, because it has been reported that this compound inhibits acid phosphatase activity (43). Some acid phosphatase activity was noted, therefore the results reported in this paper are those obtained in the presence of $\mathrm{NaK}$ tartrate and are expressed as micromoles of inorganic phosphate released per min per mg of protein, after subtraction of tissue and reagent blanks. Reaction rate was proportional to protein content for each fraction assayed. Nonspecific or alkaline phosphatase-catalyzed degradation of $5^{\prime}$ AMP was assessed by measuring the inorganic phosphate released when $5^{\prime}$ nucleotidase was inhibited by $10 \mathrm{mM}$ nickel chloride (21), and was found to be negligible. Sixteen placental samples (three membrane fractions for each sample) were assayed at any one time $(8$ midterm and 8 term placenta of the same duplicate).

Hormone iodination and binding studies. ILAs was used to study the ontogeny of an IGF receptor. The isolation, purification, and characterization of ILAs have been detailed elsewhere (46). Briefly, this slightly acidic peptide (pI 6.5) was extracted from Cohn plasma fraction IV-4 and purified by Sephadex acid chromatography and ion exchange chromatography on carboxymethyl-cellulose (CM-52). Its potency is expressed as ng equivalents of porcine insulin based on the placental insulin radioreceptor assay (45), where $1 \mathrm{ng}$ equivalent equals $25 \mu \mathrm{U}$ porcine insulin. Carboxymethyl-cellulose (CMC)-purified ILAs (minimum specific activity $380 \mathrm{mU} / \mathrm{mg}$ ) was used to prepare [ $\left.{ }^{125} \mathrm{I}\right]-\mathrm{ILAs}$ as described (46). It was further purified on a $2.2 \times 40 \mathrm{~cm} \mathrm{G}-50$ Sephadex column equilibrated with Tris $-1 \%$ BSA buffer one day before use. $\left[{ }^{125}\right.$ I]-ILAs was $90-95 \%$ precipitable by trichloroacetic acid and its specific activity ranged from $55-65 \mu \mathrm{Ci} / \mu \mathrm{g}$ based on an estimate purity of $35 \%$. Iodinated ILAs migrates as a single peak on isoelectric focusing and high pressure liquid chromatography.

Porcine insulin $(24.4 \mathrm{U} / \mathrm{mg})$ was obtained from Connaught Research Laboratories (Willowdale, Ontario) and was iodinated as previously described (45). Its specific activity ranged from $150-200 \mu \mathrm{Ci} / \mu \mathrm{g}$ and it was $95-100 \%$ TCA precipitable.
The methodology for the iodination of insulin was used to iodinate purified EGF (courtesy of Dr. R. Benveniste) to a final specific activity of $160 \mu \mathrm{Ci} / \mu \mathrm{g}$ : purification of $\left[{ }^{125} \mathrm{I}\right]-\mathrm{EGF}$ on a $\mathrm{G}-$ 50 Sephadex column as above revealed minimal iodination damage $(<5 \%)$ and $77 \%$ incorporation of $\left[{ }^{125} \mathrm{I}\right]$ as judged by TCA precipitability of radioactivity from the initial iodination mixture.

All labeled hormones were stored at $-20^{\circ} \mathrm{C}$ and used within 10 days of iodination. Incubations for the determination of membrane binding were conducted at $4^{\circ} \mathrm{C}$ in $12 \times 75 \mathrm{~mm}$ plastic tubes with shaking. The binding assay mixture consisted of Tris- $0.1 \%$ BSA buffer, $2.5 \times 10^{4} \mathrm{cpm}$ of labeled hormone (insulin, ILAs, or EGF), and membrane protein $(200 \mu \mathrm{g}$ of $600 \times g$ or $15,000 \times g$ pellets; $150 \mu \mathrm{g}$ of 100,000 pellets) in a final volume of $0.5 \mathrm{ml}$. Parallel incubations were conducted with 'excess' unlabeled hormone: $1 \mu \mathrm{g}$ insulin (Connaught Research Laboratories), $12 \mathrm{ng}$ equivalents ILAs (Sephadex-purified), or $50 \mathrm{ng}$ EGF (purchased from Collaborative Research, Waltham, MA). The assays were terminated after $20 \mathrm{~h}$ (insulin, ILAs), or $2 \mathrm{~h}$ (EGF) by the addition of $3.0 \mathrm{ml}$ ice cold Tris buffer and centrifugation at $2,000 \times g$ for $25 \mathrm{~min}$, as previously described for the insulin radioreceptor assay (45). Specific binding was calculated from the difference between pellet radioactivity bound in the absence (total binding) or presence (nonspecific binding) of excess unlabeled hormome. $\left[{ }^{125} \mathrm{I}\right]$ insulin and $\left[{ }^{125} \mathrm{I}\right]$-ILAs specific binding data were derived from triplicate determinations; $\left[{ }^{125} \mathrm{I}\right]-\mathrm{EGF}$ data were derived from duplicate determinations. Three assays were required to process all samples for both $\left[{ }^{125} \mathrm{I}\right]$-insulin and $\left[{ }^{125} \mathrm{I}\right]$-ILAs. $\left[{ }^{125} \mathrm{I}\right]$-EGF binding to all samples was assessed in one assay.

The integrity of supernatant radiolabeled hormones after the incubation period has been previously assured for term tissue under these standard incubation procedures $(27,43,46)$ and was verified in the midterm and term displacement studies of Figure 4 by precipitation of $0.2 \mathrm{ml}$ aliquots with $10 \%$ trichloroacetic acid (43). $\left[{ }^{125} \mathrm{I}\right]$-insulin, $\left[{ }^{125} \mathrm{I}\right]$-ILAs, and $\left[{ }^{125} \mathrm{I}\right]$-EGF remained from 95-100\% intact when incubated with membranes in either the presence or absence of excess unlabeled hormones.

The cytosol receptor assay for ILAs was performed as described by Guyda and Posner (22): $500 \mu \mathrm{g}$ of cytosol protein was assayed; specific binding refers to cpm displaced in the presence of excess unlabeled ILAs as noted above. Because of the accidental loss of one sample, only 14 midterm cytosols were available for the binding studies.

All specific binding data were expressed as a $\%$ of the total cpm added, and the results are reported as mean \pm S.E. The significance of the difference between midterm and term values was computed using the Student's $t$ test.

Computer-estimated values of the equilibrium affinity constants of both particulate and soluble receptors were calculated from Scatchard plots $(50)$ as previously described $(43,46)$. The plots for all the particulate receptors were curvilinear and were resolved into two linear components representing high and low affinity sites (31); those for the cytosol binding protein were linear and the line of best fit was found by regression analysis.

\section{RESULTS}

Table 1 shows the total protein recovered from $5 \mathrm{~g}$ of frozen tissue. Although it was similar between the two gestational age groups (midterm, $284 \mathrm{mg}$; term, $237 \mathrm{mg}$ ), comparison of individual fractions revealed that the $100,000 \times g$ membrane pellets obtained from term tissue contained significantly more protein than the corresponding midterm pellets. Significant midterm versus term differences were not observed for any of the other fractions analyzed.

Figure 1 shows the placental $5^{\prime}$ nucleotidase specific activity in the three membrane fractions of each gestational age group. Highest values were obtained in the $100,000 \times g$ membrane pellets. Specific activity was significantly less in each midterm fraction relative to the corresponding term fraction, ranging from $25-31 \%$ of the term values $(P<0.001)$. 
Table 1. Protein recovery: midterm versus term tissue

\begin{tabular}{lcccc}
\hline & $600 \times g$ & $15,000 \times g$ & $100,000 \times g$ & Cytosol \\
\hline Midterm $(n=15)$ & $136 \pm 11.9^{1}$ & $17.3 \pm 2.65$ & $5.56 \pm 0.30$ & $90.4 \pm 6.79$ \\
Term $(n=16)$ & $124 \pm 4.6$ & $14.5 \pm 1.24$ & $8.37 \pm 0.62$ & $86.6 \pm 4.85$ \\
$\begin{array}{l}\text { Midterm-term } \\
\quad \text { comparisons }\end{array}$ & $\mathrm{t}_{29}=1.00(\mathrm{NS})^{3}$ & $\mathrm{t}_{29}=0.96(\mathrm{NS})$ & $\mathrm{t}_{29}=4.08^{2}$ & $\mathrm{t}_{28}=0.46(\mathrm{NS})$ \\
\hline
\end{tabular}

${ }^{1} \mathrm{mg}$ protein per $5 \mathrm{~g}$ wet weight, mean \pm S.E.

${ }^{2} P<0.001$.

3 (NS), not significant.

\section{Placental Membrane 5' Nucleotidase Activity}

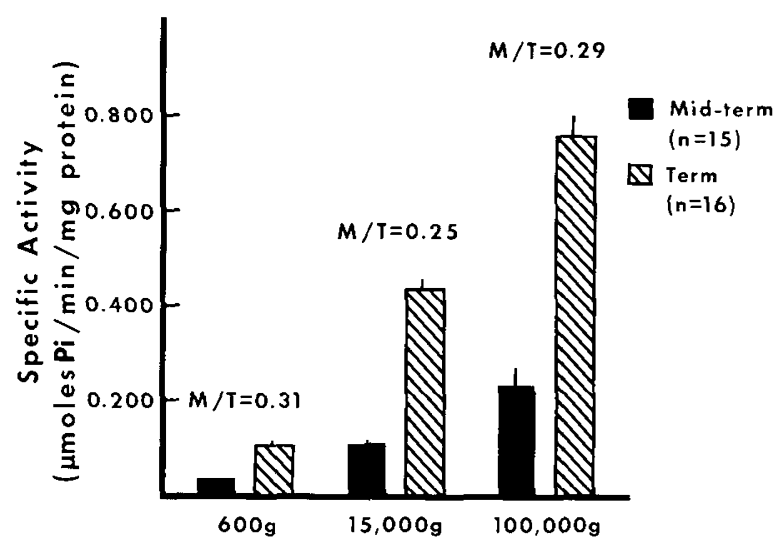

Fig. 1. Placental membrane 5 ' nucleotidase specific activity in midterm versus term placentae. The bars represent the mean of $n$ placental preparations and the vertical lines represent the S.E.

The pattern of $\left[{ }^{125} I\right]$-insulin specific binding and $\left[{ }^{125} \mathrm{I}\right]-\mathrm{EGF}$ binding (Figure 2, a and b) to midterm and term placental membranes, respectively, was similar to the distribution of $5^{\prime}$ nucleotidase specific activity in that the highest values were consistently observed in the $100,000 \times g$ membrane pellet. Furthermore, specific binding was significantly lower in all midterm fractions relative to the corresponding term fraction $(P<0.001)$, and the midterm:term ratios remained constant $(\mathrm{M} / \mathrm{T}=$ $0.28-0.42)$.

In contrast to the above observations with $\left[{ }^{125} I\right]$-insulin and $\left[{ }^{125} \mathrm{I}\right]-\mathrm{EGF}$, the profile of $\left[{ }^{125} \mathrm{I}\right]$-ILAs specific binding to midterm and term membrane fractions was markedly different (Figure 2, $a$ and $b$ ). Specific binding to midterm placentae significantly exceeded term measurements in the two low speed fractions $(P<$ $0.001)$, and was equivalent to term in the $100,000 \times g$ fraction $(P$ $>0.20$ ). Within the term group the enrichment of binding in the $100,000 \times g$ fractions was considerably less.

Figure 3 depicts the $\%$ specific binding of each labeled peptide to $500 \mu \mathrm{g}$ of midterm or term $200,000 \times g$ supernatant. Unlike the particulate fractions previously examined, the cytosol contained binding activity only for $\left[{ }^{125} I\right]-$ ILAs. Furthermore, $\left[{ }^{125} \mathrm{I}\right]-$ ILAs specific binding was significantly greater in the midterm placental cytosol than in the term placental cytosol $(P<0.001)$.

The high levels of $\left[{ }^{125} \mathrm{I}\right]$-ILAs specific binding observed in the midterm placental cytosol prompted speculation as to the nature of the ILAs receptor observed in the membrane fractions, particularly in light of the dissimilar midterm:term [ $\left.{ }^{125} \mathrm{I}\right]-$ ILAs specific binding ratios obtained relative to the other parameters studied. The possibility of contamination of the particulate receptor with a soluble ILAs binding species (and vice versa) was examined in the following mixing experiment: $4 \mathrm{mg}$ aliqouts of two midterm and two term $100,000 \times g$ membrane fractions were mixed with $5 \mathrm{ml}$ ( $15 \mathrm{mg}$ protein) of their own cytosol, or $5 \mathrm{ml}$ ( $15 \mathrm{mg}$ protein) of cytosol from the other gestational age group, or $5 \mathrm{ml}$ of sucrose, and incubated with shaking for $8 \mathrm{~h}$ at $4^{\circ} \mathrm{C}$. The time and temperature corresponded to those used to homogenize and fractionate placental tissue. At the end of the incubation, the mixtures were centrifuged at $100,000 \times g$, and the resulting pellets were washed with Tris buffer and recentrifuged to obtain the microsomal membrane. The supernatants from the first centrifugation were recentrifuged at $200,000 \times g$ to obtain the cytosol fraction employed in these studies. Finally, all fractions were assayed for protein, and diluted for the $\left[{ }^{125} \mathrm{I}\right]$-ILAs membrane and cytosol binding assays, exactly as described. The results from this experiment are shown in Table 2.

As before, $\left[{ }^{125} I\right]$-ILAs binding to midterm versus term 100,000 $\times g$ membrane fractions was not significantly different. Exposure of midterm membranes to term cytosol (containing a 'low' \% of $\left[{ }^{125} I\right]-$ ILAs specific binding) did not reduce specific binding significantly, nor did exposure of term membranes to midterm cytosol containing a 'high' $\%$ of $\left[{ }^{125} \mathrm{I}\right]$-ILAs specific binding significantly increase specific binding. A slight but not significant reduction was noted in specific binding to membranes (midterm or term) exposed to cytosol versus those exposed to sucrose. This may have been due to receptor degradation by cytosolic proteases, not unlikely in view of the length of the incubation. Receptor flux from membranes to cytosols (or sucrose) was also not observed. $\left[{ }^{125} \mathrm{I}\right]$-ILAs binding to cytosol remained unaltered regardless of the gestational age of the membrane to which it was exposed. As before, $\left[{ }^{125} I\right]$-ILAs specific binding to mid-term cytosol was significantly higher than to term cytosol.

The receptor characteristics for the three ligands were examined more closely in two representative preparations each of midterm and term placental tissue. The ability of increasing amounts of unlabeled hormones to displace radiolabeled hormones from their placental receptors is shown in Figure 4. For each hormone, similar displacement characteristics were observed in all three membrane fractions, regardless of gestational age.

Computer-estimated equilibrium constants, based on data illustrated in Figure 4, did not show any striking midterm versus term or membrane fraction differences, because they were all of the same order of magnitude for any given ligand (66).

The displacement curves for [ $\left.{ }^{125} \mathrm{I}\right]-$ ILAs binding to cytosol (Figure 4) yielded a linear Scatchard plot with a single class of high affinity binding sites $\left(\mathrm{K}_{\mathrm{A}}: 0.63\right.$ and $0.68 \times 10^{9} \mathrm{M}^{-1}$ for midterm and term respectively).

\section{DISCUSSION}

Limited placental ontogeny data are available for both the insulin receptor and two other receptors (for MSA and SM C), and primarily concern nonprimate mammalian models. In the fetal guinea pig placenta, insulin binding increases during gestation (32), in accordance with this report and previous human data $(43,47)$; however, in the fetal pig placenta, insulin binding decreases (16). Sm C binding to fetal pig placentae increases (16), as in the mouse (maternal and fetal) placenta (17), whereas in the sheep fetal placenta MSA binding decreases (39) as a function of gestational age.

These divergent results are not surprising in view of the marked difference in mammalian placentation (52), and suggest that caution should be exercised when extrapolating from animal models to the human. Furthermore, the observed heterogeneity of the IGF receptors in the placenta $(23,57)$ and in other tissues $(49,56)$ makes it conceivable that varying IGF receptor subpopulations 

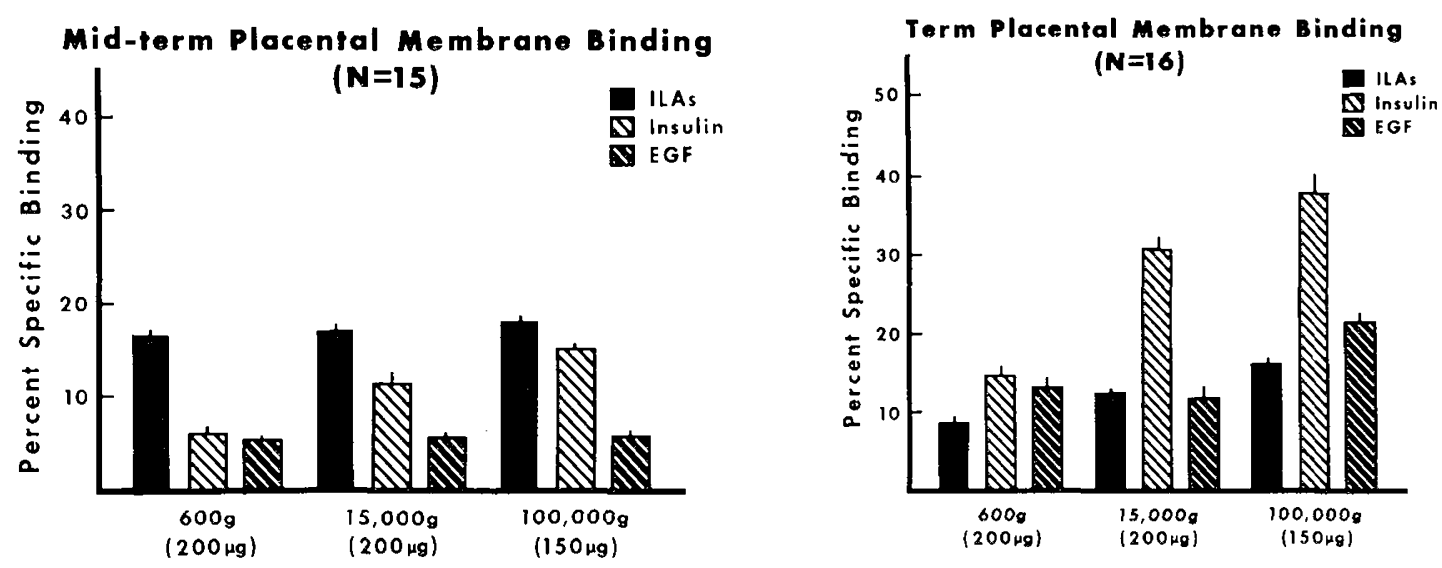

Fig. 2. (Left hand panel) specific binding of $\left[{ }^{125} \mathrm{I}\right]$-insulin-like activity (ILAs), $\left[{ }^{125} \mathrm{I}\right]$-insulin, and $\left[{ }^{125} \mathrm{I}\right]$-epidermal growth factor (EGF) to the indicated amount of midterm placental membrane protein. The bars represent the mean of $n$ placental preparations and the vertical lines represent the S.E. (Right hand panel) specific binding of $\left[{ }^{125} \mathrm{I}\right]$-insulin-like activity $(I L A s),\left[{ }^{125} \mathrm{I}\right]$-insulin, and $\left[{ }^{125} \mathrm{I}\right]$-epidermal growth factor $(E G F)$ in the indicated amount of term placental membrane protein. The bars represent the mean of $n$ placental preparations and the vertical lines represent the S.E.

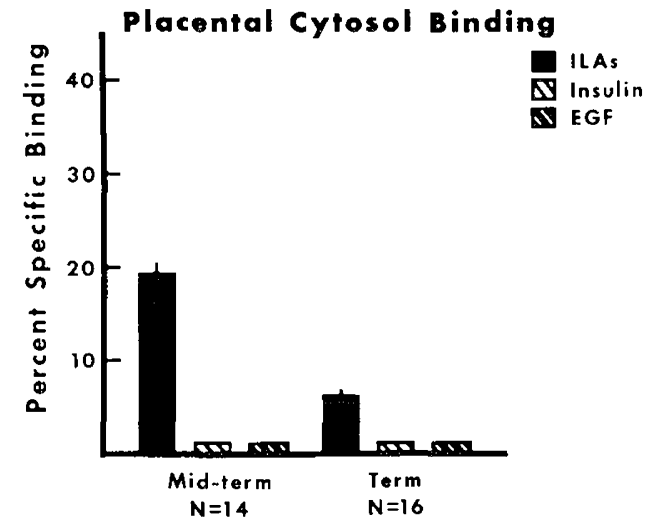

Fig. 3. Specific binding of $\left[{ }^{125} \mathrm{I}\right]-\mathrm{ILAs},\left[{ }^{125} \mathrm{I}\right]$-insulin, and $\left[{ }^{125} \mathrm{I}\right]-\mathrm{EGF}$ to mid-term vs term placental cytosol. The bars represent the mean of $n$ placental preparations and the vertical lines represent the S.E.

may be important at different times during gestation. Thus the results presented here for the human ILAs placental receptor may not be applicable to all subclasses of IGF placental receptors.

Previous human placental insulin receptor ontogeny studies (43, 47) were confined to measure binding in only one specific highspeed membrane fraction, prepared from placental homogenates and enriched in $5^{\prime}$ nucleotidase activity, a marker for microsomal membranes (19). Because of the possibility that the EGF and ILAs receptor may not have cofractionated with $5^{\prime}$ nucleotidase, and because of the possible differences which may arise in the composition of the membrane pellets due to the strikingly different architecture of midterm placenta compared to term (55), all membrane fractions $(600 \times g, 15,000 \times g$, and $100,000 \times g)$ and cytosol $(200,000 \times g$ supernatant) were analyzed for their ability to bind the three peptides. $5^{\prime}$ Nucleotidase specific activity was also measured.

The ontogeny of 5 nucleotidase specific activity appeared to parallel that of another placental membrane enzyme, alkaline phosphatase $(12,30)$, with greater activity seen at term than in midterm tissue. As observed previously (43), highest specific activity was seen in the $100,000 \times g$ fractions.

The ontogeny of the insulin and EGF receptors closely resembled the pattern of $5^{\prime}$ nucleotidase activity, with greater levels seen in term tissue. The midterm versus term difference in insulin and EGF binding persisted whether results were expressed as specific binding per mg protein or per $5 \mathrm{~g}$ starting weight.

The nonidentical subcellular distribution of EGF and insulin binding within each gestational age group may be suggestive of a different subcellular distribution of the insulin and EGF receptors.
It should be noted, however, that both insulin and EGF binding per $\mathrm{mg}$ protein were highest in the $100,000 \times g$ membrane regardless of gestational age. Similarly, when binding was expressed per $5 \mathrm{~g}$ starting tissue the $600 \times \mathrm{g}$ fraction had the highest binding capacity for both hormones in either midterm or term tissue. More complete tissue and cell disruption might well reduce the total binding capacity of this fraction (because total protein would decrease) but whether this would alter the hormone binding per $\mathrm{mg}$ protein, in this fraction or in others, is not known.

The pattern of ILAs binding was quite different: binding per mg protein was higher in midterm membranes regardless of the fraction, with the greatest differential occurring in the low speed fraction. As observed with the insulin and EGF binding studies, however, the $100,000 \times g$ pellet was enriched in ILAs binding per $\mathrm{mg}$ protein relative to the low speed fractions in both midterm and term, and the $600 \times g$ pellet had the highest binding capacity.

Although neither midterm nor term cytosol bound insulin or EGF, binding of ILAs to both gestational age group cytosols was clearly demonstrable, with significantly higher levels observed in midterm. Term placental ILAs (22) and MSA (7) cytosolic binding proteins have previously been characterized, but it is not known whether the midterm binding activity detected in this study corresponds to these molecules. The high level of ILAs specific binding in midterm cytosol is of interest in view of the increase in IGF binding proteins in midterm amniotic fluid $(10,18)$. Thus our results raise the question of whether the large molecular weight placental cytosol binding proteins (estimated molecular weight 60,000 daltons) subserve a precursor function for the smaller IGF binding proteins (estimated molecular weight 34,500 daltons) in amniotic fluid.

As discussed in conjunction with the presentations of the results, the presence of a soluble binding protein could potentially complicate the measurement of particulate membrane receptors, in that the dissimilar midterm:term ratios of ILAs binding seen in comparison with the other parameters measured could be explained by receptor or binding protein interchange between particulate and nonparticulate compartments. The data from the mixing experiments, however, suggest that the contamination of the $100,000 \times g$ membrane fraction with cytosol did not occur within this experimental design. It is therefore unlikely that contamination of midterm membrane fractions with soluble ILAs binding protein during centrifugation accounts for the dissimilar ratios of hormone binding within the high speed fractions. Similar mixing experiments for the two lower speed fractions were not performed but merit future consideration, because the larger size of the particles increases the risk of soluble receptor entrapment, despite the use of a hypotonic buffer during the membrane preparation. 
Table 2. Midterm-term mixing experiment: $\left.{ }^{125} I\right]$-insulin-like activity (ILAs) specific binding to membrane and cytosol

\begin{tabular}{cccc}
\hline \multirow{2}{*}{$\begin{array}{c}125 \\
\text { [ }] \text {-ILAs membrane } \\
\text { binding assay }\end{array}$} & \multicolumn{3}{c}{ Preincubation medium } \\
\cline { 2 - 5 } & Sucrose control & Midterm cytosol & Term cytosol \\
\hline Midterm membranes & $13.8 \pm 0.9^{2}$ & $10.9 \pm 0.2$ & $11.6 \pm 1.9$ \\
Term membranes & $12.3 \pm 0.3$ & $9.6 \pm 0.5$ & $9.6 \pm 1.5$
\end{tabular}

${ }^{125}$ I]-ILAs charcoal binding assay ${ }^{3}$

Preincubation membrane

\begin{tabular}{ccc}
\cline { 2 - 3 }$\left[{ }^{125} 1\right]-1$ As charcoal binding assay & $100,000 \times g$ midterm & $100,000 \times g$ term \\
\hline Sucrose control & Not detectable & Not detectable \\
Midterm cytosol & $10.6 \pm 0.5$ & $10.3 \pm 0.1$ \\
Term cytosol & $2.2 \pm 1.0$ & $2.4 \pm 1.2$ \\
\hline
\end{tabular}

'Before the determination of $\left[{ }^{125} \mathrm{I}\right]-$ ILAs specific binding to $100,000 \times \mathrm{g}$ membrane fractions, duplicate 4 mg aliquots of midterm or term membrane were preincubated $8 \mathrm{~h}$ at $4^{\circ} \mathrm{C}$ with $5 \mathrm{ml}$ of the indicated preincubation media. See text for experimental details.

${ }^{2}$ Specific binding, expressed as $\%$ of total cpm added, was determined in duplicate on $150 \mu \mathrm{g}$ membrane. Mean \pm S.E., $n=2$.

${ }^{3}$ Before the determination of $\left.{ }^{125} \mathrm{I}\right]$-ILAs specific binding to cytosol, duplicate $5 \mathrm{ml}$ aliquots (15 $\mathrm{mg}$ protein) of midterm or term cytosol were preincubated $8 \mathrm{~h}$ at $4^{\circ} \mathrm{C}$ with $4 \mathrm{mg}$ of the indicated $100,000 \times \mathrm{g}$ membranes. See text for experimental details.

${ }^{4}$ Specific binding, expressed as \% of total cpm added, was determined in duplicate on $500 \mu \mathrm{g}$ cytosol. Mean \pm S.E., $n=2$.
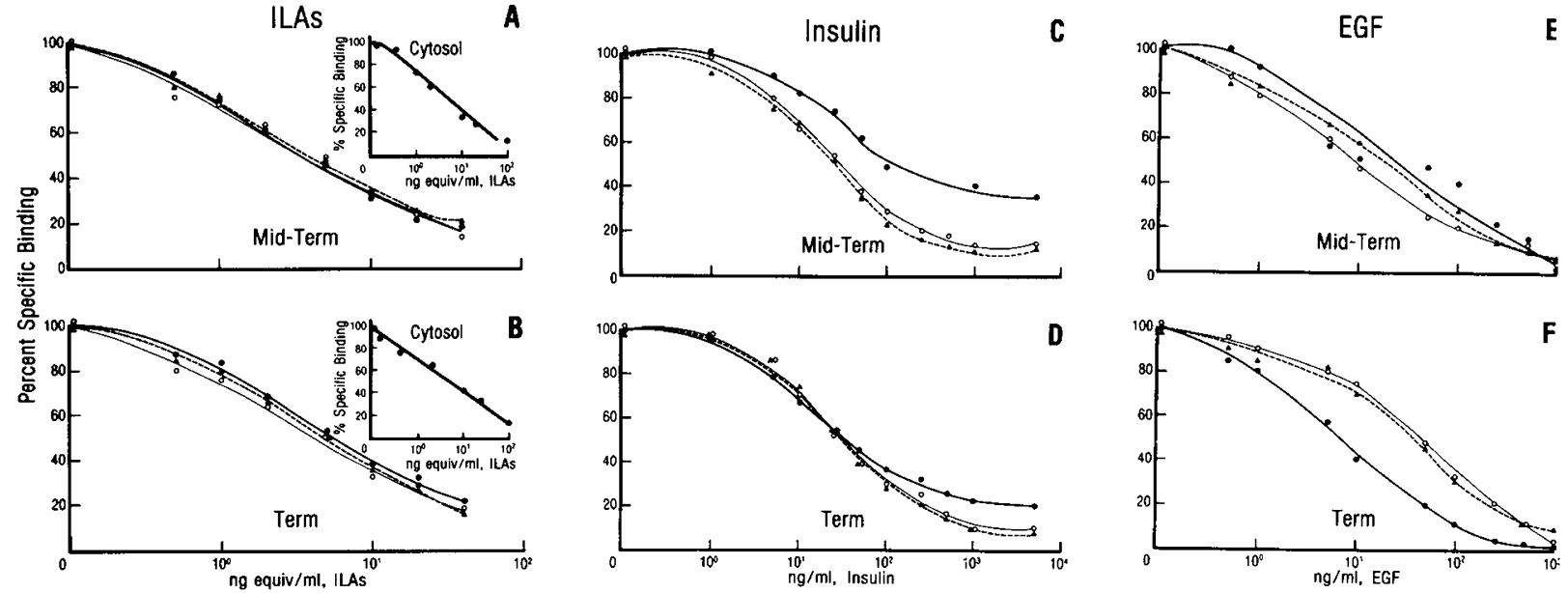

Fig. 4. Displacement of labeled hormones from particulate and soluble receptors. For this study, a $25-\mathrm{g}$ aliquot of frozen mid-term tissue (12.5 g of a $10 \mathrm{wk}$ placenta and $12.5 \mathrm{~g}$ of two $13 \mathrm{wk}$ placentae) was paired with a $25 \mathrm{~g}$ aliquot of frozen term tissue ( $12.5 \mathrm{~g}$ from each of two term placentae) and processed exactly as described in "Materials and Methods." Hormone binding was studied as detailed except that increasing amounts of unlabeled hormones in $0.1 \mathrm{ml}$ Tris-BSA were added to the incubation mixture. After subtraction of nonspecific binding [tubes containing $1 \mu \mathrm{g}$ epidermal growth hormone (EGF), $10 \mu \mathrm{g}$ insulin, or $20 \mathrm{ng}$ equivalents of ILAs], the \% of iodinated hormone bound in the absence of unlabeled hormone was set equal to 100 (maximum binding) and the remaining data was expressed as a $\%$ of this figure. All points are the mean of triplicate determinations. Main figures: $(\longrightarrow$ ) $600 \times g ;(\mathbf{A}-\mathbf{A}) 15,000 \times g ;(\mathrm{O}-\mathrm{O}) 100,000 \times \mathrm{g}$. Inset: $200,000 \times \mathrm{g}$ supernatant cytosol.

A second explanation for the dissimilar midterm:term ratios of ILAs binding may involve an alternative cell type localization of the ILAs receptor relative to $5^{\prime}$ nucleotidase and the insulin and EGF receptors. Whitsett and Lessard (59) and Nelson et al. (37) contend that human placental insulin receptors are localized on the syncytiotrophoblast, which is present in increasing amounts as gestation progresses (55). Although the documentation of ILAs (14) and EGF (29) binding to syncytiotrophoblast monolayer cultures suggests a similar localization of these receptors, no data are available as to the binding ability of other placental cell types such as the cytotrophoblast or nonparenchymal derived cell types, both of which show different age-related developmental patterns (55). Furthermore, the existence of intracellular particulate receptors for all of these peptides in other tissues $(1,44)$ raises the question as to whether there are alternative subcellular distributions of the ILAs particulate receptor relative to insulin and EGF. Because the protocol employed for the present study was clearly preparative in nature, no attempt was made to identify the subcellular organelles predominating in each fraction, nor to characterize gestational age-related differences in pellet composition.
Regardless of the possible difference in the subcellular distribution of the mid-term and term placental receptors, the Scatchard analyses suggest that the growth factor membrane receptors and the ILAs cytosol binding protein(s) are of a very similar nature with regard to their affinity characteristics in midterm versus term tissue. The equilibrium affinity constants for $\left[{ }^{125} \mathrm{I}\right]$-insulin binding fall in the range of previously reported values for insulin binding to term placental membranes $(25,36,43)$, Triton-X solubilized term placental receptors (26), and term placental syncytiotrophoblast microvillus membrane vesicles $(51,59)$. The equilibrium affinity constants for $\left[{ }^{125} \mathrm{I}\right]$-ILAs binding to midterm and term tissue are in agreement with our own previous term placental studies (46) and are almost identical to those of Daughaday et al. (13) for IGF-II binding to term placental tissue. This is not surprising in view of the marked similarities between ILAs and IGF-II (23). It should be noted that human placental membrane binding of all of the IGFs tested to date generates curvilinear Scatchard plots $(7,13,24,46,57)$, suggestive of receptor heterogeneity.

The binding of $\left[{ }^{125} \mathrm{I}\right]$-EGF to midterm and term placental tissue 
also gave rise to curvilinear Scatchard plots as has been reported in other cell types (1), but not in the human placenta (27). Methodologic differences appear to explain the discrepancy between our results and those of Hock and Hollenberg, because their analyses were obtained from studies where the maximum ligand concentration was $11 \mathrm{ng} / \mathrm{ml}$. When Scatchard analyses were performed in our laboratory on competition data (maximum ligand concentration $=600 \mathrm{ng} / \mathrm{ml}$ ) from the same paper, curvilinear plots were, in fact, also generated.

To conclude, the insulin and EGF human placental membrane receptors were present in higher amounts in terms than in early gestation placentas. In contrast, the ILAs membrane receptor appears to be present in high amounts in both gestational age groups. Furthermore, unlike insulin and EGF, ILAs was observed to bind specifically to human placental cytosol from early gestation in greater amounts than to term cytosol. These results suggest that insulin, EGF, and the IGFs should continue to receive attention as possible modulators of placental growth and function. The IGFs in particular may play a more important role in early gestation.

\section{REFERENCES AND NOTES}

1. Adamson, E. D. and Rees, A. R.: Epidermal growth factor receptors. Mol. Cell Biochem., 34: 129 (1981)

2. Ames, B. N.: Assay of inorganic phosphate, total phosphate, and phosphatases In: E. F. Neufeld, V. Ginsburg: Methods in Enzymology, Vol. 8, p. 115 (Academic Press, New York, 1966).

3. Aronson, N. N. and Touster, O.: Isolation of rat liver plasma membrane fragments in isotonic sucrose. In: Fleischer and Packer: Methods in Enzymology, Vol. 31 , p. 90 (Academic Press, New York, 1974).

4. Bahn, R. S., Speeg, K. V., Ascoli, M., and Rabin, D.: Epidermal growth factor stimulates production of progesterone in cultured human choriocarcinoma cells. Endocrinology, 107: 2121 (1980).

5. Beaconsfield, P. and Villee, C. A.: Placenta: A Neglected Experimental Animal. (Pergamon Press, New York, 1979).

6. Benveniste, R., Speeg, K. V., Carpenter, G., Cohen, S., Lindner, J., and Rabinowitz, D.: Epidermal growth factor stimulates secretion of human chorionic gonadotropin by cultured human choriocarcinoma cells. J. Clin. Endocrinol. Metab., 46: 169 (1978).

7. Brinsmead, M. W. and Liggins, G. C.: The binding of rat liver cell multiplication stimulating activity (MSA) to human placenta and serum proteins. Austra. J. Exp. Biol. Med. Sci., 56: 527 (1978).

8. Carpenter, G. and Cohen, S.: Epidermal growth factors. In: G. Litwack: Biochemical Actions of Hormones, Vol. 5, p. 203 (Academic Press, New York, 1978).

9. Carpenter, G., Poliner, L., and King, L.: Protein phosphorylation in human placenta. Stimulation by epidermal growth factor. Mol. Cell Endocrinol., 18: 189 (1980).

10. Chochinov, R. H., Mariz, I. K., Hajek, A. S., and Daughaday, W. H.: Characterization of a protein in mid-term human amniotic fluid which reacts in the somatomedin-C radioreceptor assay. J. Clin. Endocrinol. Metab., 44: 902 (1977).

11. Coltart, T. M. and Bateman, C.: Carbohydrate-induced lipogenesis in the human placenta of normal and diabetic pregnancies. Brit. J. Obst. Gynec., 82: 471 (1975)

12. Curzen, P.: Variations in the enzyme histochemistry of the placenta. J. Obst. Gynec. of Brit. Commonwealth, 71: 388 (1964).

13. Daughaday, W. H., Mariz, I. K., and Triveli, B.: A preferential binding site for insulin-like growth factor II in human and rat placental membranes. J. Clin. Endocrinol. Metab., 53: 282 (1981).

14. Deal, C. L. and Guyda, H. J.: Insulin receptors in monolayer cultures of human term placenta and choriocarcinoma cells: identification and characterization. The Endocrine Society 61st Annual Meeting, A398: 172 (1979).

15. Demers, L. M., Gabbe, S. G., Villee, C. A., and Greep, R. O.: The effects of insulin on human placental glycogenesis. Endocrinology, 91: 270 (1972).

16. D'Ercole, A. J., Foushee, D. B., and Underwood, L. E.: Somatomedin-C receptor ontogeny and levels in porcine fetal and human cord serum. J. Clin. Endocrinol. Metab., 43: 1069 (1976).

17. D'Ercole, A. J. and Underwood, L. E.: Ontogeny of somatomedin during development in the mouse. Develop. Biol., 79: 33 (1980).

18. Drop, S. L., Valiquette, G., Guyda, H. J., Corvol, M. T., and Posner, B. I.: Partial purification and characterization of a binding protein for insulin-like activity (ILAs) in human amniotic fluid: a possible inhibitor of insulin-like activity. Acta Endocrinol., 90: 505 (1979).

19. Fox, I. H. and Marchant, P. J.: Purine catabolism in man: characterization of placental microsomal 5' nucleotidase. Can. J. Biochem., 54: 462 (1976).

20. Freinkel, N.: Effects of the conceptus on maternal metabolism during pregnancy. In: B. S. Leibel, G. A. Wrenshall: The Nature and Treatment of Diabetes Mellitus, p. 679 (Excerpta Medica Foundation, Amsterdam, 1965).

21. Gerlach, U. and Hiby, W.: 5' nucleotidase. In: E. Bergmeyer: Methods of Enzyme
Analysis, Vol. 2, p. 871 (Academic Press, New York, 1974)

22. Guyda, H. J. and Posner, B. I.: Specific water-soluble binding sites for serum insulin-like peptides in human and animal tissues. Endocrinology, 106: 113 (1980).

23. Guyda, H. J., Posner, B. I., and Humbel, R. E.: Insulin-like growth factor (IGF) receptors of the human placenta: a comparative study. The Endocrine Society 63rd Annual Meeting, A 104: 108 (1981).

24. Hall, K., Fryklund, L., Low, H., Skottner, A., and Zederman, R.: Receptor binding and biological effects of somatomedin A in vitro. FEBS Lett., 48: 59 (1978).

25. Haour, F. and Bertrand, J.: Insulin receptors in the plasma membranes of human placenta. J. Clin. Endocrinol. Metab., 38: 334 (1974).

26. Harrison, L. C. and Itin, A.: Purification of the insulin receptor from human placenta by chromatography on immobilized wheat germ lectin and receptor antibody. J. Biol. Chem., 255: 12066 (1980).

27. Hock, R. A. and Hollenberg, M. D.: Characterization of the receptor for epidermal growth factor-urogastrone in human placenta membranes. J. Biol. Chem., 255: 10731 (1980).

28. Hock, R. A., Nexo, E., and Hollenberg, M. D.: Solubilization and isolation of the human placenta receptor for epidermal growth factor-urogastrone. J. Biol. Chem., 255: 10737 (1980).

29. Huot, R. I., Foidart, J. M., Nardone, R. M., and Stromberg, K.: hCG secretion and immunohistochemistry of human first trimester placenta in organ culture. In Vitro, 15: 193 (1979).

30. Jones, C. J. and Fox, H.: An ultrahistochemical study of the distribution of acid and alkaline phosphatases in placentae from normal and complicated pregnancies. J. Pathol., 118: 143 (1976).

31. Kahn, C. R., Freychet, P., Roth, J., and Neville, D. M.: Quantitative aspects of the insulin-receptor interaction in liver plasma membranes. J. Biol. Chem., 249: 2249 (1974).

32. Kelly, P. A., Posner, B. I., Tsushima, T., and Friesen, H. G.: Studies of insulin, growth hormone, and prolactin binding: ontogenesis, effects of sex and pregnancy. Endocrinology, 96: 532 (1974).

33. Litonjua, A. D.: Studies on the glucose metabolism of human term placentae: effects of insulin. Acta Med. Philippina, 3: 247 (1976).

34. Litonjua, A. D., Canlas, M., Soliman, J., and Paulino, D. Q.: Uptake of $\alpha$-aminoisobutyric acid in placental slices at term. Am. J. Obs. Gynecol., 99: 242 (1967).

35. Lowry, O. H., Rosenbrough, N. J., Farr, A. L., and Randall, R. J.: Protein measurement with folin phenol reagent. J. Biol. Chem., 193: 265 (1951).

36. Marshall, R. N., Underwood, L. E., Voina, S. J., Foushee, D. B., and Van Wyk. J. J.: Characterization of the insulin and somatomedin $C$ receptors in human placental cell membranes. J. Clin. Endocrinol. Metab., 39: 283 (1974).

37. Nelson, D. M., Smith, R. M., and Jarrett, L.: Nonuniform distribution and grouping of insulin receptors on the surface of human placental syncytial trophoblast. Diabetes, 27: 530 (1978).

38. O'Keefe, E., Hollenberg. M. D., and Cuatrecasas, P.: Epidermal growth factorcharacteristics of specific binding in membranes from liver, placenta, and other target tissues. Arch. Biochem. Biophys., 164: 518, (1974).

39. Owens, P. C., Brinsmead, M. W., Waters, M. J., and Thorburn, G. D.: Ontogenic changes in multiplication stimulating activity binding to tissues and serum somatomedin-like receptor activity in the ovine fetus. Biochem. Biophys. Res. Comm., 96: 1812 (1980).

40. Phillips, L. S. and Vassilopoulou-Sellin, R.: Somatomedins. Part 1. N. Engl. J. Med., 302: 371 (1980).

41. Phillips, L. S. and Vassilopoulou-Sellin, R.: Somatomedins. Part 2. N. Engl. J. Med., 302: 438 (1980).

42. Pilkis, S. J. and Park, C. R.: Mechanism of action of insulin. Ann. Rev. Pharmacol., 14: 365 (1974).

43. Posner, B. I.: Insulin receptors in human and animal placental tissue. Diabetes, 23: 209 (1974)

44. Posner, B. I., Gonzalez, R. M., and Guyda, H. J.: Intracellular (Golgi) receptors for insulin-like peptides in rat liver. Can. J. Biochem., 58: 1075 (1980).

45. Posner, B. I. and Guyda, H. J.: A human placental radioreceptor assay for insulin and insulin-like substances. In: H. N. Antoniades: Hormones ir, Human Blood, p. 247 (Harvard University Press, Cambridge, Mass., 1976).

46. Posner, B. I., Guyda, H. J., Corvol, M. T., Rappaport, R., Harley, C., and Goldstein, S.: Partial purification, characterization, and assay of a slightly acidic insulin-like peptide from human plasma. J. Clin. Endocrinol. Metab., 47: 1240 (1978).

47. Potau, N., Rindor, E., and Ballabriga, A.: Insulin receptors in human placenta in relation to fetal weight and gestational age. Pediatr. Res., 15: 798 (1981).

48. Rechler, M. M., Fryklund, L., Nissley, S. P., Hall, K., Podskalny, J. M., Skottner, A., and Moses, A. C.: Purified human somatomedin A and rat multiplication stimulating activity. Eur. J. Biochem., 82: 5 (1979).

49. Rechler, M. M., Zapf, J., Nissley, S. P., Froesch, E. R., Moses, A. C., Podskalny, J. M., Schilling, E. E., and Humbel, R. E.: Interactions of insulin-like growth factors I and II and multiplication stimulating activity with receptors and serum carrier proteins. Endocrinology, 107: 1451 (1980).

50. Scatchard, G.: The attractions of proteins for small molecules and ions. Ann. N.Y. Acad. Sci., 51: 660 (1949).

51. Steel, R. B., Mosley, J. D., and Smith, C. H.: Insulin and placenta: degradation and stabilization, binding to microvillous membrane receptors, and amino acid uptake. Am. J. Obst. Gynec., 135: 522 (1979).

52. Steven, D. E.: Comparative Placentation: Essays in Structure and Function (Academic Press, New York, 1975).

53. Szabo, A. J. and Grimaldi, R. D.: The effect of insulin on glucose metabolism of 
the incubated human placenta. Am. J. Obst. Gynec., 106: 75 (1970).

54. Takano, K., Hall, K., Fryklund, L., Holmgren, A., Sievertsson, H., and Uthne, $\mathrm{K}$.: The binding of insulin and somatomedin $\mathrm{A}$ to human placental membrane. Acta Endocrinol., 80: 14 (1975).

55. Teasdale, F.: Gestational changes in the functional structure of the human placenta in relation to fetal growth: a morphometric study. Am. J. Obs. Gynecol., 137: 560 (1980).

56. Thomopoulos, P., Postel-Vinay, M. C. Testa, U., Guyda, H. J., and Posner, B. I.: Receptors for insulin-like peptides (ILAs) in rat reticulocytes and erythrocytes. Endocrinology, 103: 1087 (1981).

57. Van Buul-Offers, S. and Van den Brande, J. L.: Binding of somatomedin-A and $-C$, NSILAs, and insulin to human placental cell membranes. Hormone Research, 11: 186 (1979).

58. Villee, C. A.: The metabolism of human placenta in vitro. J Biol. Chem., 205: 113 (1953).

59. Whitsett, J. A and Lessard, J. L. Characteristics of the microvillus brush border of human placenta: insulin receptor localization in brush border membranes. Endocrinology, 103: 1458 (1978).

60. Williams, P. F. and Turtle, J. R.: Purification of the insulin receptor from human placental membrane. Biochem. Biophys. Acta, 579: 367 (1979).

61. The valuable assistance of Dr. Beverly Murphy in providing the early gestational age placentae to us is gratefully acknowledged. The authors thank Mrs. Mary Youakim for secretarial assistance.

62. This study was presented, in part, at the Sixth International Congress of Endocrinology, Melbourne, Australia, February 10-16, 1980, and was published, in part, as an abstract in Clinical Research, 28: 389A (1980).

63. Drs. H. J. Guyda and B. I. Posner are both Research Scholars of the Province of Quebec.

64. This research was supported, in part, by grants from the Medical Research Council of Canada (MT- 4403 to H.J.G. and MT-4183 to B.I.P.)

65. Reprint requests should be addressed to: Dr. H. J. Guyda, Montreal Children's Hospital - D387, Division of Endocrinology, 2300 Tupper Street, Montreal, Quebec H3H 1P3, Canada.

66. ILAs: $\mathrm{K}_{1}$ mid-term: $3.3-6.8 \times 10^{9} \mathrm{M}^{-1} ; \mathrm{K}_{1}$ term: $1.5-3.2 \times 10^{9} \mathrm{M}^{-1} ; \mathrm{K}_{2}$ midterm: $1.0-4.5 \times 10^{8} \mathrm{M}^{-1}$; and $\mathrm{K}_{2}$ term: $0.3-2.5 \times 10^{8} \mathrm{M}^{-1}$. Insulin: $\mathrm{K}_{1}$ midterm: $0.2-1.6 \times 10^{9} \mathrm{M}^{-1} ; \mathrm{K}_{1}$ term: $0.5-0.9 \times 10^{9} \mathrm{M}^{-1} ; \mathrm{K}_{2}$ mid-term: $0.1-0.3 \times$ $10^{7} \mathrm{M}^{-1}$; and $\mathrm{K}_{2}$ term: $0.3-0.5 \times 10^{7} \mathrm{M}^{-1} . E G F: \mathrm{K}_{1}$ mid-term: $5.0-7.6 \times 10^{9}$ $\mathrm{M}^{-1} ; \mathrm{K}_{1}$ term: $1.3-3.1 \times 10^{9} \mathrm{M}^{-1} ; \mathrm{K}_{2}$ mid-term: $2.3-7.4 \times 10^{7} \mathrm{M}^{-1}$; and $\mathrm{K}_{2}$ term: $3.5-9.5 \times 10^{7} \mathrm{M}^{-1}$.

67. Received for publication June 24, 1981.

68. Accepted for publication March 9, 1982.

Copyright $(C) 1982$ International Pediatric Research Foundation, Inc. 0031-3998/82/1610-0820\$02.00/0 